\title{
Modern Dimensions of Jacques Maritains Political and Legal Personalism
}

\author{
Sergey S. Shestopal ${ }^{1}$ \\ Kateryna V. Astakhova ${ }^{1}$ \\ Victor V. Astakhov²
}

\author{
${ }^{1}$ Vladivostok state university of economy and service, 690014, Gogolya 41, Vladivostok, Russia \\ ${ }^{2}$ Kharkiv University of Humanities "People's Ukrainian Academy"
}

Doi:10.5901/mjss.2015.v6n6s3p192

\begin{abstract}
The paper is devoted to the discussion of the fundamental ideas of one of the most well-known French philosopher - Jacques Maritain concerning the problems of personalization and pluralism in modern democratic society. Exceptional actuality of the Maritain's treatment of the problems of the relations between laic state and believes for modern democratic countries social field are the quintessence of the paper. The fundamental questions of the philosophy of law: personalism and pluralism in the light of the concepts and interpretations of one of the brightest representatives of the French philosophical and law schools Jacques Maritain (November 18, 1882, Paris, France - April 28th 1973, Toulouse, France), which has become already the classic theorist are to be considered in the paper. Nowadays these issues seem to be particularly interesting and relevant: the transformation of sovereignty in the era of globalization, the political and the personal, mental and social transformation of the national identity and traditions on the one hand and the European integration and globalization on the other that are the challenges of the day.
\end{abstract}

Keywords: philosophy of law, natural law, personalism, pluralism, modern democracy.

\section{Introduction}

We shall consider here the fundamental contribution to the philosophy of law: personalism and pluralism of Jacques Maritain (1882 - 1973), one of the brightest representatives of French classic philosophy and legal theory. Nowadays these issues seem to be particularly interesting and relevant: the transformation of sovereignty in the era of globalization, the political and the personal, mental and social transformation of the national identity and traditions on the one hand and the European integration and globalization with other that are the challenges of the day.

Political and legal personalism and pluralism being the basic philosophical and legal categories of society are eternally in confronting and interpenetration. Their permanent unity and conflict has always been one of the basic driving forces for social and political developments of the society.

It is quite clear that these philosophical and legal categories are extremely relevant in today's realities of globalization in general and the European or the Euro-Asian integration in particular. Peculiarities introduced in the society and its legal institutions, due to the structure of the moment, characterizing by widespread protection of human rights, individual freedom ("To be free is of the essence of every intellectual being." "Freedom in the Modern World" (Maritain 1996.)), special attention to and respect for the individuals and their privacy, pluralism and globalization, associated with deterritorialization, increase in social interconnectedness across existing geographical and political boundaries and the rapidness of social activity. Constant collisions of personal, pluralistic and ignoring all boundaries global information field make modern society contradictory and internally strained as never. The colliding forces of grown globalization, localization, and personalization present a challenge for mankind. This is suggestive appeal to the pillars of modern philosophy.

Modern French social doctrine rests on the postulates of a thousand years history of Christian family values. Such fundamental issues as the ratio of pluralism and personalism in society and their philosophical and legal aspects traditionally have been in the focus of attention of French philosophers. These traditions date back to Abelard, Albert the Great, Thomas Aquinas, Boden, Descartes, Pascal, Malebranche, Montesquieu, Voltaire, Maine de Biran, de Maistre, Cousin, Renouvier. Theoretical advances of leading representatives of the French philosophy of law in the twentieth century such as Jacques Maritain, Etienne Gilson, Emmanuel Mounier, Gabriel Marcel have not less of an impact on the 
world community.

Socio-philosophical doctrine of Maritain inherits a wealth of notions and concepts (in addition to the system formative for him Thomistic tradition with its still Aristotelian components), starting with the Plato's "State", ideas of the Enlightenment and ending the studies of the Chicago school of sociology. Bergson, E. Mounier and Berdyaev had the direct influence on him. Famous American poet Thomas Stearns Eliot once called Jacques Maritain "the most conspicuous figure and probably the most powerful force in contemporary philosophy." From Maritain's point of view the observance of the humanism has three basic principles: an approval the value of the individual, co-existence of people in aspiration to the common good, as well as Christian-theistic orientation, would result in the existence of a society in which the persons' abilities will be able to be open and realize themselves most fully and also the human freedom will be implemented. Clear that governing principals like that would not be able to exist in one separate national state surrounded with the state with variety of other governing principals. Maritain suggested efficient resolution of the contradiction "a world federation of political societies" with considerable autonomy and citizens may move freely all over the federation of states if they want (Shestopal, 2014).

«Jacques Maritain a été avant tout un immense philosophe catholique, l'un de ceux qui a le plus contribué à faire revivre saint Thomas d'Aquin. II a été aussi, par la force des choses, un philosophe politique qui laisse une œuvre abondante qui, en notre époque sans repères, demeure plus que jamais actuelle pour réfléchir à frais nouveaux sur l'avenir de la Cité politique.» (Maritain, Philosophe De La Cité, Christophe Geffroy, Source : La Nef N²48 DE MAI 2103). But «In point of fact, Western philosophy has never set itself free of Christianity: wherever Christianity did not have a hand in the construction of modern philosophy it served instead as a stumbling block" J.Maritain. An Essay on Christian Philosophy (1955), p. 51.

\section{Maritain's Conception and Challenges of the Modernity}

Jacques Maritain was the first in the history of the twentieth century, who joined the philosophical and anthropological theory (personalism) with practical participation in the drafting of the Declaration of Human Rights, directed against totalitarian encroachments on these rights. Thomism for Maritain was the source of ideas and methodological paradigms throughout his creative life (Villey, 2002; Corduan, 2007; Crosson, 1983; Fay, 1991 \& Lyubashits, Mordovtsev \& Mamychev, 2015).

Speaking of pluralism and personalism, Maritain relies on his own works, "Freedom in the Modern World" (1936), Ch. I, and "Integral humanism", Ch. V. Summarizing their main points, Maritain characterizes the "new personalistic and pluralistic system."

The need for a universal state regulation has to disappear with the appearance of the new system, and all natural forms of the social and economic activity, even the largest, will originate from below, from the free initiative and competitiveness of certain groups, trade unions, the cooperative organizations, associations, producers and consumers united on a federal basis corporations - of institutionally recognized organizations of different levels. State, providing various social organizations with independent initiative and self-control in all of their inherent activities, would retain for himself the only authentic prerogative of "supreme arbitrator and supervisor regulating this arbitrary and autonomous activities from the highest political point of view of the common good" (Maritain, 1951).

Political society, giving the state authority to control and authorities for the common good, requires him not only the maintenance of public order but also the respecting justice. Maritain emphasizes the importance of ability of political society to perform the supreme control over the state, which itself is endowed with the functions of management and control" But since this supreme authority is obtained by him from a political society, that is, from the people, the state itself does not possess a natural right to the supreme power (Maritain, 1951), that is to sovereignty. However, in the sense that Maritain puts into the concept of "sovereignty" as a natural and inalienable right of the transcendent or separate supreme authority, there is no any of earthly subject possessing such right: "nor king, nor emperor in fact, were not sovereign, but had a sword and attributes of sovereignty. A state is not a sovereign and even people are not sovereign. Only God alone is sovereign» (Maritain, 1951). This extreme point of view at the sovereignty is quite a natural, acceptable, and even logically necessary for religious thinker, but is almost unacceptable to the laic philosophy of law. The acceptance of such treatment of sovereignty creates the opportunity for rather arbitrary interpretation and evaluation of the optimum of sovereignty necessary to ensure the actual legitimacy of the state and eventually the political society, which Maritain identifies with the people.

This contradiction of religious - philosophical theory with practice is a weak place in the concept of Maritain, who was striving to create a consistent concept of the supremacy of political society (people) over the state. "Speaking about people, as well as about political community, we should say that neither people not political community is not sovereign, 
but it has a natural right for complete autonomy or self-government" (Maritain, 1951). But if the people have a "natural right for complete autonomy", it means that people are sovereign, just in that sense which Maritain gives the notion of sovereignty. Now it is difficult to judge whether Maritain has noticed the contradiction he had admitted, but his further arguments have rational sense only under the assumption that the people have sovereignty nevertheless. "The people use this right when receive written or unwritten constitution of political society, or when part of them are united into a small political group, in order to work out the right, or to make a decision, or when they elects their representatives. The people always retain such a right. It was thanks to this right that the people have controlled the state and its government officials" (Maritain, 1951). The methods of such control consist in delegation of the right to create laws and govern through elections on fixed time period and with certain powers of a deputy. By giving authority to these particular persons, people, in the same degree, limit their own right to govern, but do not lose this right, as it manages through their representatives and special organs. "But man is by no means for the State. The State is for man." (Maritain, 1951) - this is the basic thesis of Maritain.

Maritain believes that if democracy enters the next historical stage "with sufficient intelligence and vitality," it will not ignore religion, as bourgeois democracy did in the past. At the same time, in turn, for the Catholic philosopher it is quite possible that this renovated, "personalistic" democracy will be a pluralistic, i.e., especially tolerant to the multi confessional religions and differences of opinion.

The development of Maritain's ideas about the necessity of transforming a laic belief into the human values and their comprehensive support in the political (civil) society can form the basis of further practical measures to strengthen the unity of the nation, regardless of ethnic, cultural, religious or atheist differences. The first step in this direction could be the improvement of the Constitution of a sovereign, laic, democratic, social state in which believers and nonbelievers share a common political purpose - to consolidate power and authority as a guarantor of rights and freedoms of its citizens.

According to Maritain, only society of a personalistic type can be truly democratic. For its formation it is necessary to complete the establishment of democratic rights.

Maritain sees the first stage of its formation in the era of the Middle Ages, when great efforts to construct life of the society based on the unity of theological convictions and religious beliefs, political and legal theory and practical life had been made. It was possible during several centuries - the majority of the modern European states and legal systems were formed during this period. However, with the coming of the Reformation this period had finished, "and return to the sacred medieval model was no longer possible" (Maritain, 1951). As a result of the Reformation, the civil or political society has become more and more detached from the spiritual authority of the church and has built a "secular" "laic" order where political and legal differences between citizens of variouse backgrounds and different religions had been erased. This process of "secularization" of political society in a New times increased due to the attempts to build a life of the society based on "pure reason" separated at all from religion. But as the cataclysms of the last two centuries had happened, "pure reason" proved incapable to provide spiritual unity of mankind.

Hence Maritain concludes: "As soon as the tragic events of recent decades disproved the bourgeois rationalism of the XVIII and XIX centuries, we had become more clearly aware of the fact that religion and metaphysics is an essential component of human culture, origin and necessary incentives of the life of society" (Maritain, 1951). Therefore, the renovated democracy of future should not ignore religion and should be pluralist and personalist type, i.e. focused on the individuals. In this personalistic political society, people belonging to different philosophical or religious trends, can and should work together for the sake of common goals and common good, if they accept the basic principles of a society of free people.

\section{What are the Basic Principles of Personalistic Democracy?}

First of all, the democracy should carry in itself support and protection for belief of common men's in freedom. Maritain considered that the dogma of bourgeois liberalism, consisting in the idea that a democratic society should provide the public arena for performances about bases of social life, where, as in the free market, the ideas and positions are facing and competing, even the most destructive with respect to the freedoms and rights was a huge mistake. Such ideological tolerance of bourgeois democracy of the XIX and first half of the XX century existed under the slogan "the freedom of opinion " made it neutral even in relation to their own freedom.

Maritain wrote: "Since it (i.e., the bourgeoisie) has not the actual common good, it has not the actual common thinking, there was no common consciousness, but only indifferent empty skull, surrounded by mirrors: it is not surprising that before World War II in those countries that have come under the influence of corrupted fascist, racist or communist propaganda, society has lost any idea of himself and faith in themselves, some sort of common belief, which could 
encourage it to confront negative processes" (Maritain, 1999). This belief is of civil or mundane character, not religious. With all the need for it in a genuine democracy, such faith cannot be imposed on citizens in the form of some kind of philosophical concept. Maritain is firmly convinced that "in our time, this concept has been able to generate only inhumane, cruel or hypocritical fake offered by totalitarian states which claim to faith, love and respect of a religious man to God; it gave birth to a desire of these countries to impose their own faith onto consciousness of the masses by the power of propaganda, lies, and the police apparatus" (Maritain, 1951). People with a variety of philosophical and religious views can come to such secular faith. This faith does not deal with the ideological and practical principles, caused by the development of the moral consciousness of the need to strive together for the common good.

Political society has the right and obligation to develop and support among the citizens a secular faith, on which the national community and civic consciousness depend. Though for the common good it is important that the practical situations, that are the base of the law of this society, were true in themselves, democratic states do not arrogates to themselves the prerogative to judge the truth of these provisions, leaving them the recognition and approval of the people themselves.

Maritain considered that the law of personalistic democracy must include the following sections:

- The human rights and freedoms, political rights and freedoms, social rights and social freedoms and the corresponding liability;

- The rights and responsibilities of persons who are part of the family society as well as freedom and liabilities of the latter in respect of the political community;

- The mutual rights and responsibilities of the State and social groups; governing people, by the people and for the people; functions of authority in political and social democracy, a conscious moral obligation concerning both just laws and the Constitution, guaranteeing to people different freedoms;

- The exclusion of the conditions for possibility of political revolutions in a society that is truly free, and is governed by laws, which changes and developments depend on the national majority;

- The equality of people, justice in relations between individuals and political society, civil concord and the ideal of fraternity, religious freedom, mutual tolerance and mutual respect between different spiritual communities and schools of thought, civil self-sacrifice and love for the Motherland, respect for its history and heritage, and also understanding of the various traditions that have intertwined forming its unity;

- The commitments of each individual in relation to the good of society and the political commitment of every nation for the common good of civilized society and the need for awareness of the unity of the world and the existence of the community of peoples (Maritain, 1999).

Maritain emphasizes that although these provisions of personalistic democracy arise from the Christian doctrine nonetheless in a democratic society there should be no religious pressure on non-Christians, who have the right to build their democratic faith on other ideological grounds: "The civil power and the state should take care of one only thing that is a common secular faith inside common secular law "(Maritain, 1999).

\section{What are the Basic Principles of Pluralism within the Democracy? How the Person Incorporates into Democratic Society?}

Maritain keeps in his imagination somehow idealistic world that is, with no doubts, pluralistics, but also he naturally puts as a basis into this world a Christian vision of the human person. His philosophy of low and political philosophy was defined by him as 'integral Christian Humanism', even "a theocentric humanism. Some transcendent ingredients in the notions of human destiny and believe are always present in his political theories; and as we already mentioned above, the superior recognition of the sovereignty of God. Surely, with incorporated into this world democracy and full of dignity, liberty and self-conciseness human beings that are individuals in terms of Maritain. Maritain describes the society with domination of law. Theorist classified four principal kinds of law: the eternal, the natural, the 'common law of civilization' (droit des gens or jus gentium), and the positive (droit positif).

Since the nature of the democratic faith is not a doctrinal but practical, the criterion of State intervention in the sphere of the expression of ideas should also be practical, not ideological. The State does not need to judge whether a political theory is heretical. It is sufficient providing guarantees of justice and legality, to decide on whether or not political heretics threatens the democratic right by their actions or that they receive from foreign state subsidies for antidemocratic propaganda. "Each time the government ignores this fundamental truth, which depends on its own nature, the reason is being sacrificed. And as reason each time takes revenge, then ultimately the political society in some way is being sacrificed "(Maritain, 1951).

However, the restrictions should not be the most important in protection of society from the political heretics. There 
are many positive and constructive means in viable democracy that are much more effective. Maritain believes that activity of professional groups and unions of citizens who devote themselves to the development of democratic philosophy, education of the people in matters of common law and intellectual struggle against subversive political movements are such means. The state itself can inform the people about the anti-democratic ideologies, charging people, known for their "wisdom and moral purity to struggle." It is important to enhance the sense of responsibility of utilization of the media in order to enable political society "to use spontaneous pressure of common conscience and public opinion originating in the clearly articulated national ethnic group, in order to prevent power of political heretics" (Maritain, 1951). But the most important meaningful tool that the political society has at its disposal - is democratic education that teaches belief in the democratic right and the organic need for it. (sic.! droit positif).

Such education is mostly dependent from the family but not from a state. Maritain believes that spiritual familiarizing with the natural law is a function of the public education system and is auxiliary in respect to the family. Public education should provide something that the family cannot give - to give children the full amount knowledge required for the formation of a civilized man. "My point of view lies in the fact that implementing this common supporting role, the educational system of the state should provide future citizens not only with the treasures of skill, knowledge, and wisdom (broad general humanitarian education for all), but also to give them a deep and elaborated belief in general the democratic rights, that is necessary for the unity of the political community " (Maritain, 1951).

Maritain clearly sees the dilemma of religious education in modern democratic school, which can be solved in two different ways: either the various religious ideas that are important to the nation are integrated into the public school system, or on the basis of each of these ideas only private schools appear.

Finally the problem is in the interconnection of the public education and family education. Where in a family or in the school the personality got its unique characteristic features? Maritain is seeking for the harmony between educated families and democratic public schools. He even prescribes the necessity of humanitarian education (that is the introduction and comfortable existence of the person in the modern stage of civilization) for every person, living in advanced democratic society. Nowadays this problem is still of great urgency (Raley, 2010; Tabachnick, 2012; Astakhova, 2013 \& Mordovtsev, Mordovceva \& Mamychev, 2015), and we have to contribute considerable efforts into its development and resolution.

\section{Concluding Remarks}

So, from the above analysis, we clearly see the consonance of many of the ideas of the French theorist with modernity. It should be proper here to appeal to Maritain's chef-d'oeuvre (Maritain, 2007) "Philosopher is a person searching for wisdom. Wisdom in fact is not among too popular goods; there was not ever overproduction in this area. The more rare the topic that philosopher presumably is interested in, the more strongly the tendency to think that society especially feel needs in a philosopher is revealed " And despite the apparent naivety of some of his ideas for modern technocratic society, the relevance and usefulness of many of his theoretical results in this global community developing at an incredible speed erasing not only the borders of states but also the borders of personality should be recognized.

\section{References}

Astakhova, E. (2013) Education as a socio-economic market the product in the new historical conditions // Educational potential of the Kharkiv region: monograph / Nar. Ukr. Acad. Kharkiv. Section. 3.1. pp. 282-289.

Chiesa, S.B. (1980) Cultura e politica in Jacques Maritain / B. Sorge // Civilta cattolica. - Roma, 1980.

Corduan, W. (2007) Neo-Thomism (Electronic resource) / W. Corduan. Mode of access: http://mb-soft.com/believe/txo/neothomi. htmlastupdatedon 05/31/2007.

Crosson, F.J. (1983) Maritain and natural rights / F.J. Crosson // Rev. of metaphysics. Wash. Vol. 36, № 4. pp. $897-912$.

Fay, Th.A. (1991) Maritain on rights and natural law / A.Th. Fay // Thomist. Wash. Vol. 55, № 3. pp. 439-448.

Lyubashits, V.Y., Mordovtsev, A.Y. \& Mamychev, A.Y. (2015) State and Algorithms of Globalization // Mediterranean Journal of Social Sciences. Vol 6, No 3 S6. pp. 269-277.

Maritain, J. (1996) Integral Humanism, Freedom in the Modern World, and A Letter on Independence, Revised Edition (ND Maritain Collected Works). pp. 368.

Maritain, J. (1987) l'Ordre des concepts (logique) / J. Maritain // Jacques et Raissa Maritain. Oeuvres completes. Fribourg (Suisse): Editions universitaires / Paris Editions Saint-Paul. Vol. II. pp. 277-765.

Maritain, J. (1999) La loi naturelle ou loi non ecrite / J. Maritain // Jacques et Raissa Maritain. Oeuvres completes. Fribourg (Suisse): Editions universitaires. Paris: Editions Saint-Paul. Vol. XVI. pp. 918.

Maritain, J. (1951) Man and the State. University of Chicago Press, Chicago, ILL. pp. 196.

Maritain, J. (2007) Le philosophe dans la cite. Editeur Parole et Silence (6 septembre 2007). Paris. pp. 227. 
Miller, F.D. \& Biondi, Carrie-Ann (2015) A Treatise of Legal Philosophy and General Jurisprudence. Volume 6: A History of the Philosophy of Law from the Ancient Greeks to the Scholastics. Springer, 2015. pp. 444.

Mordovtsev, A.Y. \& Mordovceva, T.V. \& Mamychev, A.Y. (2015) The Convergence of Law: The Diversity of Discourses // Mediterranean Journal of Social Sciences. Vol. 6, № 3. pp. 257-26.

Possenti, V. (1983) Philosophie du droit et loi naturelle selon Jacques Maritain / V. Possenti // Revue thomiste. Paris; Bruxelles. T. 83, № 4. pp. $598-608$.

Raley, Y. \& Preyer, G. (2010) Philosophy of Education in the Era of Globalization, Taylor \& Francis, NY, Routledge. pp. 246.

Shestopal, S. (2014) Political and Legal personalism and pluralism J. Maritain's concept and treatment // Theory and practice of jurisprudence, 1(5), pp. 32. Retrieved from: http://nauka.jur-academy.kharkov.ua/download/el_zbirnik/1.2014/13.3.pdf.

Sorge, B. (1980) Chiesa, cultura e politica in Jacques Maritain / B. Sorge // Civilta cattolica. Roma. A. 131, vol. 4, № 3130. pp. $356-366$. Tabachnick, D. \& Koivukoski, T. (2012) Globalization, Technology, and Philosophy, SUNY Press. pp. 257. 